\title{
Perspectives for Using Light QuAlity KNOWLedge AS AN Advanced Ecophysiological Weed Management TOOL ${ }^{1}$
}

\author{
Perspectivas da Utilização da Qualidade da Luz Como uma Avançada Ferramenta \\ Ecofisiológica para o Manejo de Plantas Daninhas
}

\author{
MEROTTO Jr., A. ${ }^{2}$, FISCHER, A.J. ${ }^{3}$ e VIDAL, R.A. ${ }^{4}$
}

\begin{abstract}
The current knowledge of light quality effects on plant morphogenesis and development represents a new era of understanding on how plant communities perceive and adjust to available resources. The most important consequences of light quality cues, often mediated by decreasing in red far-red ratios with respect to the spectral composition of incident sunlight radiation, affecting weed-crop interaction are the increased plant height and shoot to root ratio in anticipation of competition by light quantity, water or nutrients. Although the concepts related to light quality have been extensively studied and several basic process of this phenomenon are well known, little applications of photomorphogenic signaling currently are related to agricultural problems or weed management. The objectives of this review are to describe how light quality change can be a triggering factor of interspecific interference responses, to analyze how this phenomenon can be used to predict weed interference, to reevaluate the critical periods of interference concept, and to discuss its potential contribution towards developing more weed competitive crop varieties. Knowledge on light quality responses involved in plant sensing of interspecific competition could be used to identify red/far-red threshold values, indicating when weed control should be started. Light quality alterations by weeds can affect grain crop development mainly in high yielding fields. Unlike the traditional concept or the critical period of competition, light quality mediated interference implies that the critical period for weed control could start before the effects of direct resource (water, nutrients and available light) limitation actually occur. The variability in light quality responses among crop genotypes and the identification of mutants insensitive to light quality effects indicate that this characteristic can be selected or modified to develop cultivars with enhanced interspecific interference ability. Knowledge on light quality-elicited responses represents a new possibility to understand the underlying biology of interspecific interference, and could be used in the development of new weed management technologies.
\end{abstract}

Keywords: critical period for weed control, crop-weed interactions, red/far-red ratio, shade-avoidance, weed thresholds.

RESUMO - O atual conhecimento sobre os efeitos da qualidade da luz representa uma nova era da compreensão dos processos envolvidos na percepção e ajuste das plantas em função dos recursos disponiveis no ambiente. As consequências mais importantes da diminuição da qualidade de luz, que se relaciona principalmente com a diminuição da relação vermelho/ vermelho-extremo, que ocorrem nas interações entre culturas e plantas daninhas são o aumento da estatura e da relação parte aérea/raiz. Essas alterações são tentativas de antecipar os efeitos da concorrência futura por quantidade de luz, água ou nutrientes. Embora vários conhecimentos básicos relacionados com a qualidade da luz tenham sido desenvolvidos há muito tempo, poucas aplicações da sinalização fotomorfogênica têm sido implementadas em processos relacionados com a agricultura e, principalmente, com o manejo de plantas daninhas. Os objetivos deste trabalho foram: descrever a diminuição da qualidade da luz como um fator desencadeante da competição interespecífica; analisar como a qualidade da

Recebido para publicação em 14.11.2008 e na forma revisada em 5.6.2009.

2 Prof. Adjunto, Departamento de Plantas de Lavoura, Universidade Federal do Rio Grande do Sul - UFRGS, Av. Bento Gonçalves, 7712, Caixa Postal 15.100, 91501-970 Porto Alegre-RS, Brasil, <merotto@ufrgs.br>; ${ }^{3}$ Prof. Associado, Weed Science Program, Department of Plant Sciences, University of California, Davis, California, USA; ${ }^{4}$ Prof. Associado, Departamento de Plantas de Lavoura - UFRGS. 
luz pode ser usada para predizer o início da interferência das plantas daninhas; reavaliar os períodos críticos de interferência; e discutir o potencial de desenvolvimento de cultivares mais competitivas com as plantas daninhas. O conhecimento dos fatores envolvidos na qualidade da luz pode ser utilizado para identificação de uma relação da radiação vermelho/ vermelho-distante que indique o início da competição interespecífica e possa ser usada com um nivel de dano referencial, indicando quando o controle das plantas daninhas deve ser iniciado. Os efeitos da baixa qualidade de luz podem limitar o desenvolvimento das culturas, sobretudo em situações de lavouras com elevados niveis potenciais de rendimento de grãos. Nessas situações, o período crítico para controle de plantas daninhas deve ser considerado antes de se iniciarem os efeitos da limitação dos recursos de água, nutrientes e quantidade de luz, que representa o tradicional periodo crítico de competição. A existência de variabilidade de genótipos das culturas à qualidade da luz e a identificação de mutantes insensiveis aos efeitos da baixa qualidade da luz indicam que essa característica pode ser selecionada ou transformada para o desenvolvimento de cultivares com maior capacidade de competição com as plantas daninhas. Os conhecimentos relacionados com a qualidade da luz representam uma nova possibilidade de compreender a biologia da competição interespecífica e poderão ser utilizados no desenvolvimento de novas tecnologias para o manejo de plantas daninhas.

Palavras-chave: interações cultura-planta daninha, nível de dano econômico, período crítico de competição, relação vermelho/vermelho-distante, resposta de fuga ao sombreamento.

\section{INTRODUCTION}

Negative weed interference is one of the most important factors reducing crop grain yields worldwide (Oerke, 2006). Weed management practices raise health and environmental concerns and increase crop production costs. Several methods of weed control have been developed mainly through chemical or mechanical approaches. In addition, considerable research has contributed towards understanding factors involved in crop susceptibility to negative interspecific interference and for using crops as direct weed suppressors (Gibson $\&$ Fischer, 2004). However, critical knowledge gaps persist and this technology has yet to be fully developed as a novel method for weed control. But only limited attention has been devoted to the ability of crops to suppress weeds through light quality (spectral distribution of the irradiance reaching plants) cues.

Interspecific competition between crops and weeds occurs mainly for light, water and nutrients (Aguilera et al., 1990; Rajcan \& Swanton, 2001). The direct effect of light quantity upon photosynthesis and ontogenesis characterizes this resource as one of the most important factors affecting plant growth (Jiao et al., 2007). However, the effects of light on a plant community are not only related to the magnitude of the photosynthetic photon flux (PPFD) reaching plant canopies but also to the quality, direction and duration of the irradiance (Smith, 2000). Therefore, new and advanced strategies for weed management require understanding of all light interactions within crop communities in order to predict interspecific interference and minimize crop losses due to weeds. Most light quality effects involved in weed and crop interactions are related to reductions in the red far-red $(\mathrm{R} / \mathrm{Fr})$ ratios of light reflected by or transmitted through plant canopies (Aphalo \& Ballaré, 1995) and crop susceptibility to growth alterations in response to light quality changes. Understanding light quality effects in cropping systems represents a new phase in theorizing about weed-crop interactions by studying perception and signaling networks under multiples stress responses (Rajcan \& Swanton, 2001; Kumar \& Wigge, 2007). Several studies report differential plasticity between crops and weeds in response to interspecific interference (Sattin et al., 1994; Gibson et al., 2004; Agostinetto et al., 2008; Fleck et al., 2008). A common feature in these studies is the analysis of morphological traits in order to explain the superior competitiveness of a given genotype. However, the molecular and physiological factors behind these morphological traits are poorly studied. Although the concepts related to light quality 
have been extensively studied and several processes of this phenomenon are well understood, little knowledge on photomorphogenic signaling is being applied to agricultural problems and to weed management. Results of studies regarding light quality effects in crop communities have recently been presented and current knowledge allows designing further research towards applying this concept to improve crop management and weed control.

The objective of this review is to describe how light quality can be a factor triggering interspecific interference and to propose innovative ideas to use this factor to predict and manage weed interference. First, we provide a brief overview of the basic concepts related to light quality and to the potential effects resulting when weeds affect light quality interactions in crop communities. Then, we describe studies proposing the use of the plant light signaling weed interference prediction as an advanced strategy for weed management. Finally, we discuss the potential for using artificial transformation or the natural variability in crop sensitivity to light quality effects to develop weed-suppressive crop genotypes.

\section{BASIC CONCEPTS OF LIGHT QUALITY}

\section{Physiology of light quality in plants}

As a consequence of their sessile character, plants are not able to move away from stresses or to choose better spots to grow. However, plants are not totally passive and have evolved an impressive range of signaling pathways in order to adapt and survive at a low fitness cost against biotic and abiotic stresses. Light signals are perceived in plants through phytochromes, cryptochromes, phototropins and not yet well described pigment receptors of UVB radiation (Ballaré \& Casal, 2000; Nagy et al., 2001; Jiao et al., 2007; Kevei et al., 2007). Although these photoreceptors interact, phytochromes are presumably the most important pigments controlling plant growth and development (Han, 2007; Kevei et al., 2007). Phytochrome-mediated physiological and photomorphogenic responses involve processes such as germination, etiolation, shade avoidance, chloroplast movement, circadian rhythm and flowering (Han et al., 2007; Jiao et al., 2007). The change in light quality due to shading refers to a reduction in the $\mathrm{R} / \mathrm{Fr}$ ratio below a canopy, regarding the spectral distribution of incident light above the canopy, due to selective chlorophyll light absorption of red and reflection of far-red light (Aphalo \& Ballaré, 1995; Weinig \& Delph, 2001). Plant pigments absorb light in wavelengths ranging from $300 \mathrm{~nm}$ to $700 \mathrm{~nm}$ (violet to red light). Unabsorbed irradiance from $710 \mathrm{~nm}$ to $730 \mathrm{~nm}$ (far-red) is reflected or transmitted and altered $\mathrm{R} / \mathrm{Fr}$ ratios are perceived as signals by phytochromes of neighboring plants (Kurepin et al., 2007a). Although the $\mathrm{R} / \mathrm{Fr}$ ratio has been described as the main cue of aboveground sensing among plants, other sensors (blue light, light intensity and ethylene) have also been shown to serve as aboveground competition cues (Franklin \& Whitelam 2005; Vandenbussche et al., 2005; Murphy \& Dudley, 2007).

\section{Signaling factors related to light quality}

Light quality effects in plants are determined by the transitions between the photoconvertible biological inactive form phytochrom red (Pr) and the active form phytochrome far-red (Pfr) (Jiao et al., 2007). The expression of effects resulting from this transition involves several genes and physiological processes. The Phytochrome Interacting Factors (PIF) is a set of transcription factors shown to be the central player of gene expression control in the light quality effects network (Castillon et al., 2007; Monte et al., 2007). The phytochrome photoreceptors network regulates the expression patterns of $\sim 10$ to $30 \%$ of the entire plant transcriptome (Kevei et al., 2007). Comparison of gene expression between corn and Abutilon theophrasti Merrik growing in competition indicated that red light signaling, carbon utilization and cell division were rapidly changed during interspecific competition between these plants (Horvath et al., 2007). Differential regulation of compounds whose levels are affected by light quality signals may reflect different susceptibility to competition in different species or crop varieties. The kinase PKS1 is involved in Pfr migration from 
the cytoplasm to the nucleus and is relevant to the final effect of light quality on phytochrome dynamics (Smith, 2000). However, the complete regulation of kinases and PIFs is not fully understood (Castillon et al., 2007). The concentration and efficiency of these compounds that can control the dynamics of $\mathrm{R} / \mathrm{Fr}$ signaling is probably highly variable in different species and crop varieties.

Physiological regulation through light quality signals may also involve plant hormones. Phytochrome acts through multiple signal transduction pathways, and ethylene, auxin and mainly gibberillin act as messengers of light quality effects on cell growth (Von Armin \& Deng, 1996; Jensen et al., 1998). For example, a low $\mathrm{R} / \mathrm{Fr}$ ratio reduced ethylene levels in 7-day-old sunflower seedlings causing stem elongation, while increasing gibberillin $\mathrm{A}_{1}$ and indole-3-acetic acid contents in both internodes and leaves (Kurepin et al., 2007a,b). According to Kusaba et al. (1998) GA $_{53}$ and $\mathrm{GA}_{20}$ are precursors of $\mathrm{GA}_{1}$, expressed through gen $\mathrm{OSH} 1$ and catalyzed by GA-20 oxydase. Therefore the expression of the $\mathrm{OSH} 1$ gene and the activity of GA-20 oxydase could explain the different competitive ability detected through morphological trait analysis among crop genotypes.

Plant sensing is not only functional in aboveground interactions but also appears to regulate belowground interference. Plants are able to anticipate root competition even prior to resource limitation by increasing biomass allocation to roots (O'Brien et al., 2005). Interestingly, these results contrast with the light quality-mediated sensing of aboveground competition, which results in decreased root growth (Rajcan et al., 2004). Recently, Murphy \& Dudley (2007), studying the interaction between above- and belowground sensing, confirmed the independence of these responses. However, further mechanisms of root sensing and the independence of responses to canopy light signaling are not fully described in the literature.

\section{Effects of light quality on plant development}

Several processes are involved in the emission, capture, processing and distribution of light quality signals among plants (Ballaré et al., 1995; Smith, 2000; Weining, 2000). The photoreceptor system is able to detect early light quality signals resulting from plant interactions within a community (Briggs \& Olney, 2001). As a consequence of these signals, plant growth is continuously adjusted in avoidance of competition stress. Light quality effects are important not only in modulating initial plant growth but also in determining plant metabolism until reproduction (Sattin et al., 1994). Most light quality studies deal with the basic mechanism of molecular induction (Whitelam \& Smith, 1991; Briggs \& Olney, 2001; Kevei et al., 2007) or with effects upon seed germination, organ orientation, leaf senescence, accelerated flowering, plant branching and self-thinning adjustment (Patterson, 1985, Davis \& Simons, 1994; Ballaré \& Casal, 2000; Takano et al., 2001; Rajcan et al., 2004). However, the most consistent light quality-induced effects are stem elongation (Ballaré et al., 1990, Crotser et al., 2003; Lund et al., 2007; Bell \& Galloway, 2007) and increased shoot to root ratio (Rajcan et al., 2004; Murphy \& Dudley, 2007), which enable anticipation and avoidance of competition for light, water or nutrients. Light quality signals can also exert inhibitory effects; for example, light with a low R/Fr ratio reaching the stem reduced seed set in potted sunflower plants (Libenson et al., 2002). Plant responses to reduced $\mathrm{R} / \mathrm{Fr}$ ratio are not consistent across species, varying in the magnitude of consequences and affected traits (Leicht \& Silander, 2006). The diversity of responses to light quality signals can be related to the evolution of active plasticity among species and plants (Bell \& Galloway, 2007). According to these authors, the increase in plant height in response to low $\mathrm{R} / \mathrm{Fr}$ light may not occur in understorey plants because it would never sufficiently increase these plants' light capture possibilities.

\section{APPLICATIONS OF LIGHT QUALITY KNOWLEDGE TOWARDS WEED MANAGEMENT}

Light quality effects can trigger processes that determine differential interspecific competitive hierarchies between plants in a community. According with this hypothesis, 
crops would be less competitive than weeds if they are more sensitive to inhibitory light quality effects or because of a lower capacity for modifying the quality of light transmitted or reflected by their canopies as to affect weed development. Alternatively, weeds can be more tolerant and more effective than crops in altering the light quality reaching neighboring crop plants. In addition, weeds are usually present at greater densities than crop plants, which potentially increases weed chances to affect the light quality environment. Recent molecular and biochemical knowledge about light quality signaling among plants can be used to explore relationships between weeds and crops. These concepts can be utilized in order to develop new knowledge for weed management regarding prediction and mitigation of weed interference with crops. The classical theories about weed interference need to be reevaluated in the light of this new knowledge regarding plant interactions.

The increasing of stem elongation is hypothesized as a strategy to improve light interception in highly competitive communities (Ballaré et al., 1990). One of the main light quality effects is to promote stem elongation. Thus light quality indicates the proximity of neighbors that will eventually compete for resources in the near future as plants develop proceeds. However, light-qualityinduced stem elongation may imply different trade-offs in crops and weeds. Decreased branching and aboveground biomass as a consequence of stem elongation caused by low R/Fr (Casal \& Smith, 1988; Merotto Jr.et al., 2002) can be more prejudicial to crops than to weeds. According to Weinig \& Delph (2001) induced elongation at early stages of plant development correlate with decreased plasticity at later stages. In crops, the comparatively greater damages of light quality effects relate to impairment of initial development, which, in turn, is directly related to grain yield. This may mainly occur in fields that allow for the expression of high yield potential. In weeds, plasticity may compensate for the consequences of light quality effects and future competitive ability may not be compromised.

The characterization of light quality effects on weed-crop interactions can be used to test one of the paradigms of weed and crop interference, which refers to the bases for the superior competitive ability of a particular crop genotype. According to that paradigm, greater competitive ability could result from comparatively higher growth rates or be due to insensitivity to the negative effects of competition. The plant photoreceptor system is able to detect early light quality signals occurring during plant interactions in a community, which allows for continuous adjustment of plant growth (Briggs \& Olney, 2001), such as elongation for improved light capture in presence of neighbors. Thus, light quality cues can provide some measure of insensitivity or avoidance of the stress of competition (Ballaré \& Casal, 2000). Elucidation of light quality effects caused by weeds upon crops could provide information on the onset of physiological processes related to interspecific competition and thus improve our understanding of weed-crop competition.

\section{Delimitation of weed-free periods according with light quality effects}

The classical theories of weed-crop interaction consider water, nutrients and light quantity as resources involved in interspecific competition (Aguilera et al., 1990; Rajcan \& Swanton, 2001). The relevance of light to photosynthesis indicates that this factor is one of the most important in plant competition. However, light quality signals may affect plant development before the onset of competition for available light quantity, nutrients and water (Von Arnim \& Deng, 1996). By preventing competition for water, nutrients and light quantity between weeds and rice using physical barriers and placing weeds weeds only in the inter-row, Merotto Jr. et al. (2002) found that light quality interference alone decreased aboveground rice dry mass and tillering. In addition, Von Arnim \& Deng (1996) found that plant growth two days after emergence was already inhibited by light quality-dependent effects.

The developmental changes potentially elicited in crop plants by weeds through light quality interference are not necessarily of the same magnitude as the adverse effects resulting from competition for growth resources. Light quality effects determine only 
that the negative interference of weeds upon crops may begin before competition for limited water, nutrient or light supply actually takes place. The premature effect of weeds caused by light quality determines that the period of weed tolerance before the onset of crop damage by interference may be shorter than that conceived in a traditional "critical period" approach that considers only competition for limited resources. Vidal et al. (2008) proposed the term "initialism" to describe those initial effects of plant interactions caused by light quality events. Rajcan et al. (2004) described the benefits of weed control in corn at the three to four leaf stage. At this stage, corn plants are not shaded yet by weeds, the soil usually has sufficient moisture due to irrigation or rain, and there are abundant nutrients because fertilizers have been just applied. In this situation, light quality effects explain the negative early-season impact of small weed seedlings upon corn grain yield (Williams et al., 2008). Thus, light quality interference determines negative weed effects that are already present before competition for light, water and nutrients actually starts.

The critical period of weed control refers to a period between the initiation of competition damage caused by weeds and finalizes when weeds cause no more grain yield losses (Knezevic, 2002; Silva et al., 2009). Assuming light quality altered by weeds is an important factor affecting crop development, the critical period of competition should be considered as starting before the effects of direct resource limitation of water, nutrients and light. Figure 1 illustrates this proposition and suggests that yield reduction due to early light quality interference should be comparatively more pronounced in situations where abundance of growth resources favors high crop yields. Under such conditions, the effect of limiting resources would be minimal and the interference of weeds changing the quality of light would remain as the key and early factor determining the negative effects of interspecific interference. Otherwise, in situations where environmental resource availability is conducive to only intermediate or low crop yields, the limitations of water, nutrients and light quantity overcome in magnitude the initial crop development alteration due to light quality interference by weeds. (Figure 1). Therefore, the proposed adjustments regarding the onset and magnitude of initial weed interference may be potentially relevant in situations where high crop yield potential can be expressed.

Yield potential has been increased for several crops in the last decades and the levels of resource supply were concomitantly increased to satisfy the demands of the higher yielding plant genotypes. Management practices such as plant density and distribution, optimum planting time and fertilizer supply (quantity and timing) were adjusted to the increased requirements of the new high-yielding varieties in several crops (Mann, 1997). However, current theories about weed-crop interference were mostly developed regardless of crop yield potential and may underestimate the effects of weed interference under the management conditions tailored for the modern and more efficient crop genotypes. In addition, the predominant post-emergence characteristic of newly developed herbicides and the wide adoption of transgenic crops resistant to post-emergent herbicides has decreased the utilization of pre-emergence herbicides or preventive early weed control methods. Moreover, farmers often delay their post-emergence herbicide applications to eliminate a greater number of weeds by encompassing plants from early and late weed emergence flushes (Vidal et al., 2005).

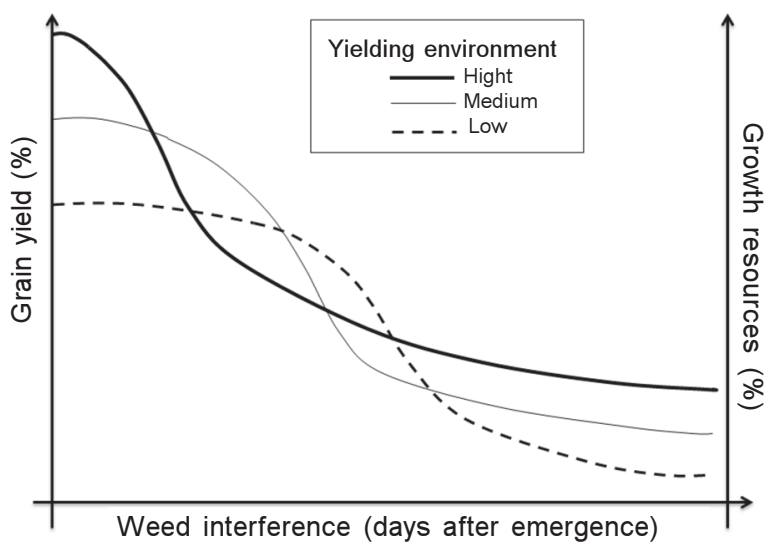

Figure 1 - Proposed differential impact of weed interference caused by light quality according to the amount of resources available and yield environmental availability. 
In those situations, crop yield penalties will involve the added effect of the initial light quality interference.

In light of the several basic concepts regarding light quality outlined here and the applied studies regarding light quality interference already reported in the literature, the concepts related to the underlying causes that determine the amplitude of the critical period of competition should be updated. However, it is still difficult to assign reference value to any fixed point in time or specific plant stage as indicator of the initiation of light quality interference due to the great variability among crops and weed species, plant distribution and densities in the field and environmental fluctuations. Therefore, it may be more adequate to identify specific $\mathrm{R} / \mathrm{Fr}$ values within a plant community that correspond to actual interference signals sensed by plants and that can serve as threshold values for weed control.

\section{Light quality as a threshold value for weed control}

The amplitude and characteristics of the critical period of competition, which is empirically determined through field experimentation, greatly depend upon the level or density of weed infestation. Density threshold values for weed control have been typically characterized as the minimum number of weeds per unit area that economically justifies weed control (Coble \& Mortensen, 1992). Many studies have determined threshold values for several weed and crop associations (Moorthy et al., 1998; Vidal et al., 2004; Fleck et al., 2006; Galon et al., 2007) and their interaction with weed emergence time (Bisnix \& Swanton, 1997), herbicide rates (Sikkema et al., 2007) and seedbank dynamics using simulations (Munier-Jolain et al., 2002). However, these values are highly variable depending on specific crop genotype characteristics, occurrence of biotic and non-biotic stresses, weed species and development stage. In most situations, crop-weed communities involve plants from different weed species and sizes. Therefore, use of a certain threshold value of weed infestation for weed control is difficult because the effect of the referred weed density may vary in different fields and years. Alternatively, the starting period of weed interference may be more realistically determined through a physiological indicator of plant interactions. Measurements of $\mathrm{R} / \mathrm{Fr}$ ratios could be used as indicators of the beginning of light quality effects as predictors of the onset of weed-crop interference as proposed in Figure 2a. Therefore, a critical $\mathrm{R} / \mathrm{Fr}$ ratio should indicate the beginning of weed interference. In addition, the same critical $\mathrm{R} / \mathrm{Fr}$ ratio at early crop stages can be related with grain yield losses (Figure $2 \mathrm{~b}$ ). This association can be modeled as a sigmoid instead of the more common hyperbolic fit described in most of the interspecific competition studies since the R/Fr ratio may be able to detect the weed effects on grain yield at very low weed densities and at early crop developmental stages. In opposition, the relation of weed interference and $\mathrm{R} / \mathrm{Fr}$ ratio
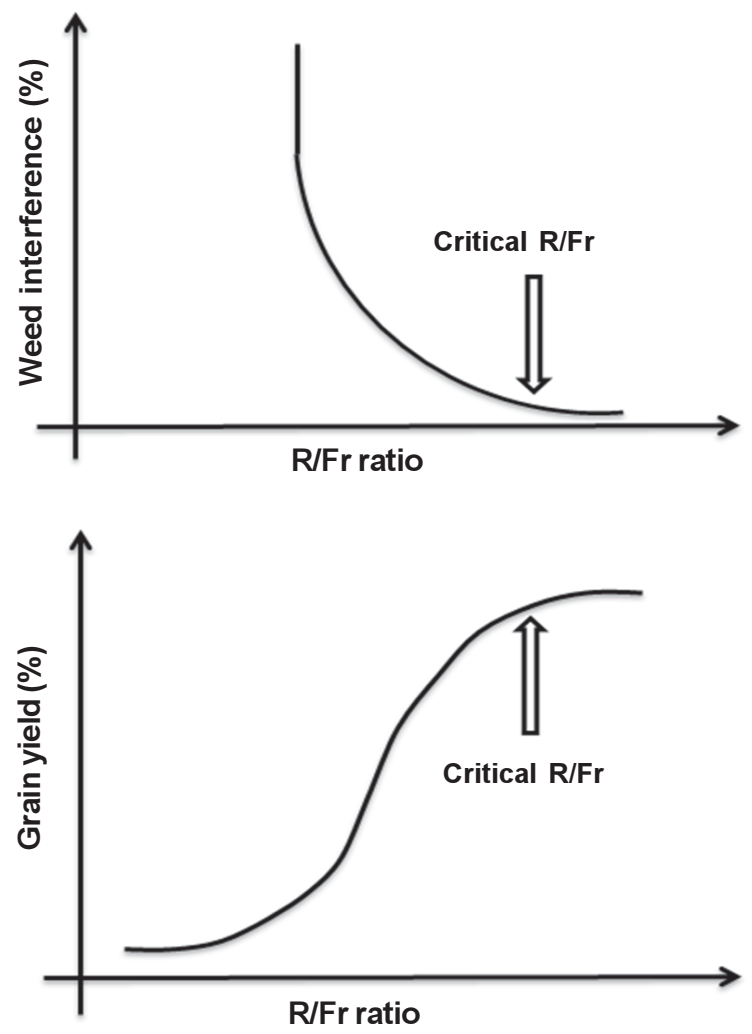

Figure 2 - Proposed models for the identification of the R/Fr ratio threshold that indicates the beginning of weed interference (a) and the effects on grain yield losses (b). 
should follow a hyperbolic model (Figure 2a) since the $\mathrm{R} / \mathrm{Fr}$ ratio should be constant at very high weed densities. Thus, instead of the traditional threshold values based upon weed density and time of competition, the $\mathrm{R} / \mathrm{Fr}$ ratio may be a more reliable and useful criterion for predicting weed interference, since it reflects the actual presence of one or several weed species from different sizes that will ultimately interfere with the crop. Commercially available light sensors allow easy measurement of $\mathrm{R} / \mathrm{Fr}$ ratios in the field. Therefore, critical R/Fr need to be established for use as a reference in making decisions about weed-crop interference. These reference values need to be supported by correlations with competition studies involving weed density/yield loss relationships and traditional critical periods of competition.

Light quality has already been proposed as an indicator of crop growth and development. Many studies described the importance of light quality for tillering initiation and death in wheat and several grasses (Casal et al., 1986; Skinner \& Simmons, 1993; Almeida et al., 2000; Evers et al., 2007). A threshold $\mathrm{R} / \mathrm{Fr}$ value ratio of $0.2-0.5$ measured at the base of canopy has been proposed to indicate the initiation of tiller death and the need for nitrogen fertilization in wheat (Sparkes et al., 2006). As a reference, the $\mathrm{R} / \mathrm{Fr}$ ratio under a fully developed soybean canopy is usually about 0.10 , whereas 1.15 to 1.19 are typical values under full sunlight (Smith, 1982; Sattin et al., 1994; Merotto Jr. \& Fischer, 2002).

\section{Light quality effects and crop genotypes with larger interspecific competition ability}

Several studies have found differences among crop genotypes in relation to weed interference (Fischer et al., 1997; Bianchi et al., 2006; Fleck et al., 2006; Murphy et al., 2008; Rigoli et al., 2009). Variability of specific morphological traits has been correlated with the interspecific competition in these studies. In addition, studies on gene expression (Horvath et al., 2007) and quantitative trait loci (QTL) (Coleman et al., 2001; De Vida, 2007) identified putative loci associated with interspecific competition. These studies represent an inovative approach for searching more competitive crop genotypes. However, the various genetic and physiological events involved in light quality responses represent opportunities to further understand the bases of differences among crop cultivars in terms of light interference with weeds. This can be further related to the ability of crops to suppress weeds or tolerate their presence.

Several evidences suggest opportunities for crop genotype manipulation in relation to light quality effects. For example, Franklin \& Whitelam (2007) found that light quality signals increase expression of cold related genes in Arabidopsis, suggesting light and temperature interactions in plants. In addition, Brutnell et al. (2007) described the identification of shade avoidance responses in maize through comparative genomic with Arabidopsis. This study suggests opportunities for using knowledge on phytochrome signaling to modify crop canopy architectures to develop more competitive crop genotypes.

The general idea of light quality as a tool for weed management is related to crop domestication process. Thus, certain traits determinig crop sensitivity to light quality effects may have been lost during the process of domestication, contributing to the lower competitiveness of modern crop genotypes. Highly weed competitive crop genotypes could be less sensitive to adverse light qualityelicited growth effects or be more sensitive to positive stimulation of mechanisms to avoid shading by neighbors. Alternatively, the quality of light reflected by or transmitted through the canopies of certain crop cultivars could also have an adverse effect on weed growth. Recently obtained knowledge on plant photoreceptors can be applied to weedcrop associations as an ecophysiological tool to improve understanding and mitigation of negative interspecific interference.

There appears to be considerable variability among crop genotypes regarding light quality sensitivity and ability to emit light quality signals, which could be used in the selection and development of crop cultivars with greater interspecific interference ability. These cultivars could either have reduced sensitivity to inhibitory effects by low $\mathrm{R} / \mathrm{Fr}$ ratios or could, alternatively, have greater ability to reflect low $\mathrm{R} / \mathrm{Fr}$ ratios to inhibit weed growth. 
A 5-fold $\mathrm{R} / \mathrm{Fr}$ reflection range was found among 14 rice varieties under field conditions (Merotto Jr. \& Fischer, 2002), indicating the presence of substantial genotypic variability regarding this trait. Reduced sensitivity to low R/FR could be built into crops through conventional selection and breeding or using transgenic technology. Studies with wheat have demonstrated genotypic variability in tillering responses to increasing plant density (Almeida et al., 2001; Casal, 2008) where certain cultivars were less sensitive to adverse light quality reflections by plants of the same species. It would be logical to infer that this same intraspectic variability in crop sensitivity to light quality signaling could operate in response to light quality cues emmited by weeds. Maloof et al. (2001) found a 100-fold variability in light quality responses among many Arabidopsis genotypes when compared to a phytochrome A insensitive mutant. In this same study, the authors found that certain natural genotypes had similar growth patterns as the low $\mathrm{R} / \mathrm{Fr}$ insensitive mutant. In addition, tall lines were less affected by low $\mathrm{R} / \mathrm{Fr}$ than short lines and genotypes from low latitudes were taller than genotypes from high latitudes. Therefore, it is conceivable that certain traits could be utilized as estimators of the differential sensitivity to low $\mathrm{R} / \mathrm{Fr}$ in other species.

The transgenic expression of genes related to the signaling and processing of light quality can provide a faster and specific improvement of crop interference ability. The overexpression of phytochrome genes can result in reduced plant response to low $\mathrm{R} / \mathrm{Fr}-$ induced elongation inhibition (Ballaré \& Casal, 2000). Many studies on photoreceptor genetic control have been developed in Arabidopsis where five phytochromes (phyA to E) were identified (Monte et al., 2007; Kurepin et al., 2007a). Among these phytochromes, phyA and phyB are considered to be the most important regarding R/Fr signaling (Heggie \& Halliday, 2005). Besides Arabdopsis, other species have been studied to understand and utilize the photoreceptor signaling variability. Takano et al. (2001) found a phytochrome A rice mutant insensitive to far-red light. These authors also reported that far-red radiation induced the expression of genes that were not involved in the expression of phytocrome A, suggesting that other photoreceptors may be involved in far-red light perception by rice plants. In addition, Robson et al. (1996) described ectopic overexpression of a phytochrome cDNA gene in tobacco causing plant failure to elongate in response to low $\mathrm{R} / \mathrm{Fr}$ ratio. These authors tested plants transformed with this trait under increasing plant densities in a field experiment and concluded that the transformed plants exhibited greater harvest indices and no productivity penalty than the nontransformed plants.

These studies reveal that the development of crop genotypes with low sensitivity to far-red light is achievable and that the potential tradeoffs related with this characteristic can be insignificant in comparison with the gain of a more competitive genotype. The main factor explaining the possible absence of tradeoffs about this phenomenon is that this alteration is not related with an increasing number of morphological structures on the plant. In opposition, the insensitivity to far-red light allows plants to maintain regular growth patterns rather than developing less efficient growth patterns in response to light cues. Regulatory mechanisms to prevent exaggerated plant responses in situations where escaping canopy shading by neighbors was unlikely were recently discovered (Jiao et al., 2007). Obtaining crops with superior ability to interfere with weeds involving light quality interactions requires development of genotypes with high expression of genes conferring low susceptibility to far-red light, and their evaluation in the field under far-red light reflected or transmitted by weed canopies.

\section{Additional strategies for using light quality to improve weed management}

Light quality reaching plants can be manipulated through ground covers using natural or artificial mulches (Kapesbauer, 1992). This approach has limited large-scale crop application but is perfectly feasible in horticultural systems. The effect of cover crops in reducing weed infestation is also attributed to light quality alteration. However, the real magnitude of the light quality effect from cover crops is obscured by the confounding effects upon water and temperature dynamics and the release of allelophatic compounds. Certainly, 
the weed suppressive effect of cover crops relates more to competition for resources than to light quality interference.

Another possible use of light quality knowledge towards weed control relates to the light requirement of weed seeds for germination. Botto et al. (1998) suggested that night-time soil tillage resulted in decreased weed seed germination compared with day-time tillage. The effect of light quality and quantity in stimulating weed seedling emergence is highly species- and seasonspecific (Baskin \& Baskin, 1998). This strategy could be used as an additional integrated weed management tactic, provided a thorough knowledge exists on the light requirements for germination for most weeds present in a given field, and provided a feasible way of implementation can be devised.

The recent characterization of light quality effects among plants initiates a new phase in the application of theoretical knowledge towards understanding and manipulating weed-crop interactions. Weed interference resulting from light quality interactions before the onset of competition for growth resources among plants may limit crop growth in high-yielding environments. Traditional empirical approaches to predict the onset of weed-crop interference are highly location-, density-, and species-specific to be reliably reproducible. Evidences about plant photoreceptor physiology suggests $\mathrm{R} / \mathrm{Fr}$ ratios can be used to set threshold values signaling the initiation of weed-crop interference. The recent understanding of the molecular regulation of physiological processes by light quality cues has the potential to be used for developing genotypes with enhanced ability to interfere with weeds through conventional breeding or biotechnological transformation. Knowledge on light quality induced effects offers new possibilities for understanding the underlying biology of interspecific interference and for developing new weed management technologies.

\section{LITERATURE CITED}

AGOSTINETTO, D. et al. Competitividade relativa entre cultivares de arroz irrigado e biótipo de capim-arroz (Echinochloa spp.). Planta Daninha, v. 26, n. 4, p. 757-766, 2008.

Planta Daninha, Viçosa-MG, v. 27, n. 2, p. 407-419, 2009
AGUILERA, J. et al. Light quality effect on photosynthesis and efficiency of carbon assimilation in the red alga Porphyra leucosticta. J. Plant Physiol., v. 157, n. 1, p. 86-92, 2000.

ALMEIDA, M. L.; MUNDSTOCK, C. M.; SANGOI, L. Tiller evocation by light quality in wheat plants cultivated in different substrates. R. Bras. Fisiol. Veg., v. 12, n. 1, p. $25-26,2000$

APHALO, P. J.; BALLARÉ, C. L. On the importance of information acquiring systems in plant-plant interactions. Funct. Ecol., v. 9, n. 1, p. 5-14, 1995

BALLARÉ, C. L.; CASAL, J. J. Light signals perceived by crop and weed plants. Field Crops Res., v. 67, n. 2, p. $149-160,2000$.

BALLARÉ, C. L.; SCOPEL, A. L.; SÁNCHEZ, R. A. Far-red radiation reflected from adjacent leaves: an early signal of competition in plant canopies. Science, v. 247, p. 329-332, 1990.

BALLARÉ, C. L.; SCOPEL, A. L.; SÁNCHES, R. A. Plant photomorphogenesis in canopies, crop growth, and yield. Hortic. Sci., v. 30, n. 6, p. 1172-1181, 1995

BASKIN, C. C.; BASKIN, J. M. Seeds: ecology, biogeography, and evolution of dormancy and germination San Diego: Academic Press, 1998. 666 p.

BELL, D. L.; GALLOWAY, L. F. Plasticity to neighbour shade: fitness consequences and allometry. Funct. Ecol., v. 21, n. 6, p. 1146-1153, 2007.

BIANCHI, M. A.; FLECK, N. G.; DILLENBURG, L. R. Partição da competição por recursos do solo e radiação solar entre cultivares de soja e genótipos concorrentes. Planta Daninha, v. 24, n. 4, p. 629-639, 2006.

BOSNIÆ, A. C.; SWANTON, C. J. Influence of barnyardgrass (Echinochloa crus-galli) time of emergence and density on corn (Zea mays). Weed Sci., v. 45, p. 276-282, 1997.

BOTTO, J. F. et al. The effect of light during and after cultivation with different tillage implements on weed seedling emergence. Weed Sci., v. 46, p. 35-357, 1998.

BRIGGS, W. R.; OLNEY, M. A. Photoreceptors in plant photomorphogenesis to date: five phytochromes, two cryptochromes, one phototropin, and one superchrome. Plant Physiol., v. 125, n. 1, p. 85-88, 2001.

BRUTNELL, T. Enhancing the agronomic performance of grasses through the manipulation of light signaling pathways. Comp. Biochem. Physiol.- Part A: Molec. Integrat. Physiol., v. 146, p. S231-S232, 2007. 
CASAL, J. J. Light quality effects on the appearance of tillers of different order in wheat (Triticum aestivum). Ann. Appl. Biol., v. 112, n. 11, p. 167-173, 2008.

CASAL, J. J.; SÁNCHEZ, R. A.; DEREGIBUS, V. A. The effect of plant density on tillering: the involvement of R/FR ratio and the proportion of radiation intercepted per plant. Environ. Exper. Bot., v. 26, n. 4, p. 365-371, 1986.

CASAL, J. J.; SMITH, H. Persistent effects of changes in phytochrome status on internode growth in light-grown mustard: occurrence, kinectics and locus of perception.

Planta, v. 75, n. 2, p. 214-220, 1988.

CASTILLON, A.; SHEN, H.; HUQ, E. Phytochrome interacting factors: central players in phytochrome-mediated light signaling networks. Trends Plant Sci., v. 12, n. 11, p. 514-521, 2007.

COBLE, H. D.; MORTENSEN, D. A. The threshold concept and its application to weed science, Weed Technol., v. 6, n. 1, p. 191-195, 1992.

COLEMAN, R. D.; GLL, G. S.; REBETZKE, G. J. Identification of quantitative trait loci for traits conferring weed competitiveness in wheat (Triticum aestivum L.). Aust. J. Agric. Res., v. 52, n. 11/12, p. 1235-1246, 2001.

CROTSER, M. P.; WITT, W. W.; SPOMER, L. A. Neutral density shading and far-red radiation influence black nightshade (Solanum nigrum) and eastern black nightshade (Solanum ptycanthum) growth. Weed Sci., v. 51, n. 2, p. 208-213, 2003.

DAVIS, M. H.; SIMMONS, S. R. Tillering response of barley to shifts in light quality caused by neighboring plants. Crop Sci., v. 34, p. 1604-1610, 1994.

DE VIDA, F. P. Rice (Oryza sativa L.) plant traits dissection for early vigor and competitiveness with Echinochloa phyllopogon (Stapf) Koss. 2007. 102 f. Thesis (Ph. D. in Ecology) - University of Califórnia, Davis, 2007.

EVERS, J. B. et al. Simulating the effects of localized red: farred ratio on tillering in spring wheat (Triticum aestivum) using a three-dimensional virtual plant model. New Phytol., v. 176, n. 2, p. 325-336, 2007.

FISCHER, A. J.; RAMIREZ, H. V.; LOZANO, J. Suppression of junglerice (Echinochloa colona (L.) Link) by irrigated rice cultivars in Latin America. Agron. J., v. 89, n. 3, p. 516-552, 1997.

FLECK, N. G. et al. Competitividade relativa entre cultivares de arroz irrigado e biótipo de arroz-vermelho. Planta Daninha, v. 26, n. 1, p. 101-111, 2008.

FLECK, N. G. et al. Interferência de Raphanus sativus sobre cultivares de soja durante a fase vegetativa de desenvolvimento da cultura. Planta Daninha, v. 24, n. 3, p. 425-434, 2006.
FRANKLIN, K. A.; WHITELAM, G. C. Light-quality regulation of freezing tolerance in Arabidopsis thaliana. Nat. Genet., v. 39, n. 11, p. 1410-1413, 2007.

FRANKLIN, K. A.; WHITELAM, G. C. Phytochromes and shade-avoidance responses in plants. Ann. Bot., v. 96, n. 1, p. 169-175, 2005.

GALON, L. et al. Economic threshold level for barnyardgrass (Echinochloa spp.) control decision in flooded rice (Oryza sativa). Planta Daninha, v. 25, n. 4, p. 709-718, 2007.

GIBSON, K.; FISCHER, A. J. Competitiveness of rice cultivars as a tool for crop-based weed management. In: INDERJT, S. J. Weed biology and management. Dordrecht, Kluver, 2004. p. 518-537.

HAN, Y. J.; SONG, P. S.; KIM, J. I. Phytochrome-mediated photomorphogenesis in plants. J. Plant Biol., v. 50, p. 230-240, 2007.

HEGGIE, L.; HALLIDAY, K. J. The highs and lows of plant life: temperature and light interactions in development. Int. J. Dev. Biol., v. 49, p. 675-687, 2005.

HORVATH, D. P.; LLEWELLYN, D.; CLAY, S. A. Heterologous hybridization of cotton microarrays with velvetleaf (Abutilon theophrasti) reveals physiological responses due to corn competition. Weed Sci., v. 55, p. 546-557, 2007.

JENSEN, P. J.; HANGARTER, R. P.; ESTELLE, M. Auxin transport is required for hypocotyl elongation in light-groth but not dark-growth Arabdopsis. Plant Physiol., v. 116, n. 2, p. 455-462, 1998.

JAO, Y. L.; LAU, O. S.; DENG, X. W. Light-regulated transcriptional networks in higher plants. Nature Rev. Gen., v. 8, n. 3 , p. $217-230,2007$

KASPERBAUER, M. J. Phytochrome regulation of photomorphogenesis in green plants: from the Beltsville spectrograph to colored mulch in field. Photochem. Photobiol., v. 56, n. 5, p. 823-832, 1992

KEVEI, E.; SCHAFER, E.; NAGY, F. Light-regulated nucleocytoplasmic partitioning of phytochromes. J. Exper. Bot., v. 58, n. 12 , p. $3113-3124,2007$.

KNEZEVIC, S. Z. Critical period for weed control: the concept and data analysis. Weed Sci., v. 50, n. 6, p. 773-786, 2002.

KUMAR, V:; WIGGE, P. A. Red sky in the morning, shepherd's warning. Nat. Genet., v. 39, p. 1309-1310, 2007.

KUREPIN, L. et al. Uncoupling light quality from light irradiance effects in Helianthus annuиs shoots: putative roles for plan thormones in leaf and internode growth. J. Exper. Bot., v. 58, p. 2145-2157, 2007a. 
KUREPIN, L.; WALTON, L.; REID, D. Interaction of red to far red light ratio and ethylene in regulating stem elongation of Helianthus annuus. Plant Growth Reg., v. 51, n. 1, p. 53-61. $2007 b$.

KUSABA, S. et al. Decreased GA(1) content caused by the overexpression of OSH1 is accompanied by suppression of GA 20-oxidase gene expression. Plant Physiol., v. 117, p. $1179-1184,1998$

LEICHT, S. A.; SILANDER, J. A. Differential responses of invasive Celastrus orbiculatus (Celastraceae) and native C. scandens to changes in light quality. Am. J. Bot., v. 3 , p. 972-977, 2006.

LIBENSON, S. et al. Low red to far-red ratios reaching the stem reduce grain yield in sunflower. Crop Sci., v. 42, p. $1180-1185,2002$

LUND, J. B.; BLOM, T. J.; AASLYNG, J. M. End-of-day lighting with different Red/Far-red ratios using lightemitting diodes affects plant growth of Chrysanthemum $x$ morifolium. Hortscience, v. 42, n. 7, p. 1609-1611, 2007.

MALOOF, J. N. et al. Natural variation in light sensitivity of Arabidopsis. Nat. Genet., v. 29, n. 4, p. 441-446, 2001

MANN, C. Reseeding the green revolution. Science, v. 277, n. 5329 , p. $1038-1043,1997$

MEROTTO Jr., A. et al. Interferência das plantas daninhas sobre o desenvolvimento inicial de plantas de soja e arroz através da qualidade da luz. Planta Daninha, v. 20, v. 1, p. 9$16,2002$.

MEROTTO Jr., A.; FISCHER, A. J. Variability of red-far-red rations in the light reflected and transmsitted by rice cultivars as an indicator of competitiveness against weeds. In: MEETING OF THE WEED SCIENCE SOCIETY OF AMERICA, 2002, Jacksonville. Abstract... Jacksonville: 2002. v. 43. p. 26.

MONTE, E. et al. Out of the dark: how the PIFs are unmasking a dual temporal mechanism of phytochrome signaling. J. Exper. Bot., v. 3. n. 58, p. 3125-3133, 2007.

MOORTHY, B. T. S.; DAS, T. K. Threshold level of weed umbrella sedge (Cyperus iria) in upland rice (Oryza sativa) under rainfed direct-seeded condition. Indian J. Agric. Sci., v. 68, n. 1, p. $7-8,1998$

MUNIER-JOLAIN, N. M.; CHAUVEL, B.; GASQUEZ, J Long-term modelling of weed control strategies: analysis of threshold-based options for weed species with contrasted competitive abilities. Weed Res., v. 42, n. 2 p. 107-122, 2002

MURPHY, G. P.; DUDLEY, S. A. Above- and belowground competition cues elicit independent responses. J. Ecol., v. 95, n. 2, p. 261-272, 2007.
MURPHY, K. M.; DAWSON, J. C.; JONES, S. S. Relationship among phenotypic growth traits, yield and weed suppression in spring wheat landraces and modern cultivars Field Crops Res., v. 105, n. 1/2, p. 107-115, 2008.

NAGY, F.; KIRCHER, S.; SCHAFER, E. Intracellular trafficking of photoreceptors during light-induced signal transduction in plants. J. Cell Sci., v. 114, n. 3, p. 475-480, 2001.

O'BRIEN, E. E; GERSANI, M.; BROWN, J. S. Root proliferation and seed yield in response to spatial heterogeneity of belowground competition. New Phytol., v. 168, n. 2 , p. $401-412,2005$.

OERKE, E. C. Crop losses to pest. J. Agric. Sci., v. 144, n. 1, p. $31-43,2006$

PATTERSON, D. T. Comparative ecophysiology of weeds and crops. In: DUKE, S. O. Weed Physiology.

Reproduction and ecophysiology. Boca Raton, CRC Press, 1985. p. $102-129$.

RAJCAN, I.; SWANTON, C. J. Understanding maize-weed competition: resource competition, light quality and the whole plant. Field Crops Res., v. 71, n. 1, p. 139-150, 2001.

RAJCAN, I.; CHANDLER, K. J.; SWANTON, C. J. Redfar-red ratio of reflected light: a hypothesis of why early season weed control is important in corn. Weed Sci., v. 52, p. 774-778, 2004.

RIGOLI, R. P. et al. Potencial competitivo de cultivares de trigo em função do tempo de emergência. Planta Daninha, v. 27, n. 1, p. $41-47,2009$.

ROBSON, P. R. H. et al. Genetic engineering of harvest index in tobacco through overexpression of a phytochrome gene. Nat. Biotechnol., v. 14, n. 8, p. 995-998, 1996

SATTIN, M.; ZUIN, M. C.; SARTORATO, I. Light quality beneath field grown maize, soybean, and wheat canopies red:far red variations. Physiol. Plant., v. 91, n. 2, p. 322-328, 1994.

SIKKEMA, P. et al. A comparison of reduced rate and economic threshold approaches to weed management in a corn-soybean rotation. Weed Technol., v. 21, n. 3, p. 647$655,2007$.

SKINNER, R. H.; SIMMONS, S. R. Modulation of leaf elongation, tiller appearance and tiller senescence in spring barley by far-red light. Plant, Cell Environ., v. 16, n. 5, p. 555-562, 1993.

SILVA, A. F. et al. Período anterior à interferência na cultura da soja-RR em condições de baixa, média e alta infestação.

Planta Daninha, v. 27, n. 1, p. 57-66, 2009. 
SMITH, H. Light quality, photoperception, and plant strategy. Ann. Rev. Plant Physiol., v. 33, p. 481-518, 1982

SMITH, H. Phytochromes and light signal perception by plants? An emerging synthesis. Nature, v. 407, p. 585-591, 2000 .

SPARKES, D. L.; HOLME, S. J.; GAJU, O. Does light quality initiate tiller death in wheat? Eur. J. Agron., v. 24, n. 3, p. 212-217, 2006.

TAKANO, M. et al. Isolation and characterization of rice phytochrome A mutants. Plant Cell, v. 13, n. 3, p. 521-534, 2001.

VANDENBUSSCHE, F. et al. Reaching out of the shade. Curr. Opin. Plant Biol., v. 8, p. 462-468, 2005.

VIDAL, R. A. et al. Nível do dano econômico de Brachiaria plantaginea na cultura de milho irrigado. Planta Daninha, v. 22, n. 1, p. 63-69, 2004.

VIDAL, R. A.; FLECK, N. G; MEROTTO Jr., A. Weedy period prior to economic loss (WEEPPEL): A new approach to weedy and weed-free periods. Planta Daninha, v. 23, n. 3, p. 387-396, 2005.
VIDAL, R. A. et al. Initialism: a new term to describe the first mechanism of negative interaction between weeds and crops. J. Plant Disease Protec., v. 21, n. 1, p. 95-98, 2008.

VON ARNIM, A.; DENG, X. W. Light control of seedling development. Ann. Rev. Physiol. Plant Molec. Biol., v. 47, p. 215-243, 1996.

WEINIG, C. Plasticity versus canalization: population differences in the timing of shade-avoidance responses. Evolution, v. 54, n. 2, p. 441-451, 2000.

WEINIG, C.; DELPH, L. F. Phenotypic plasticity early in life constrains developmental response later. Evolution, v. 55, n. 5, p. 930-936, 2001.

WHITELAM, G. C.; SMITH, H. Retention of phytochrome-mediated shade avoidance responses in phytochrome-deficient mutants of Arabidopsis, cucumber and tomato. J. Plant Physiol., v. 139, n. 1, p. 119.125, 1991.

WILLIAMS, M.; BOYDSTON, R. A.; DAVIS, A. S. Differential tolerance in sweet corn to wild-proso millet (Panicum miliaceum) interference. Weed Sci., v. 56, n. 1, p. $91-96,2008$ 